\title{
PRODUCT INNOVATION IN SMALL COMPANIES: MANAGING RESOURCE SCARCITY THROUGH FINANCIAL BOOTSTRAPPING
}

\author{
LARS LÖFQVIST \\ Faculty of Engineering and Sustainable Development, \\ University of Gävle, SE-801 76, Gävle, Sweden \\ lars.lofqvist@hig.se
}

Published 11 October 2016

\begin{abstract}
Researchers have proposed that scarce resources are the main factor hindering product innovation in small companies. However, despite scarce resources, small companies do innovate, so the research question is: How do small companies manage resource scarcity in product innovation? To answer the research question a multiple case study of three small established companies and their product innovation was used, including interviews and observations over a period of five months. The small companies were found to use many different bootstrapping methods in combination within their product innovation. The methods can be classified into three different functional categories: bootstrapping methods for increasing resources, for using existing resources more efficiently, and those for securing a fast payback on resources put into product innovation. Due to their resource scarcity, the studied companies also favoured an innovation strategy only involving new products done with known technology and targeting existing markets. This strategy seems to avoid unsuccessful innovation but at the same time exclude technologically radical innovation.
\end{abstract}

Keywords: Product innovation; resources; resource scarcity; small company; financial bootstrapping; innovation management; small enterprise; small business; small firms, SME.

\section{Introduction}

It is generally known that small companies have scarce resources, a situation that Adams (1982) and Rothwell and Dodgson (1994) specifically propose hinders

This is an Open Access article published by World Scientific Publishing Company. It is distributed under the terms of the Creative Commons Attribution 4.0 (CC-BY) License. Further distribution of this work is permitted, provided the original work is properly cited. 


\section{Löfqvist}

product innovation. Despite resource scarcity, small companies do product innovation (Vossen, 1998; SCB, 2016). Since product innovation demands and consumes lots of resources (Smith, 2009), it is challenging to understand how small companies perform their product innovation when sufficient resources do not seem to be present. Where do the resources come from and how are they used within product innovation? This study aims to contribute new knowledge to small business research and innovation management by investigating how small companies manage resource scarcity regarding personnel, knowledge and capital in their product innovation.

\section{Theoretical Framework}

To be able to investigate how resource scarcity is managed in small companies' product innovation, some relevant research on small companies, innovation and resources will be reviewed.

\section{Small companies and product innovation}

This study defines the small company as a company with less than 50 employees, in accordance with the definition by the European Union (2003). Furthermore, these small companies are established within their market, which excludes newly started small companies. Innovation can be done in many different fields, but this study focuses on product innovation, defined as the process within companies of developing and commercialising new products such as new or improved goods and/or services.

Small companies are proposed to have many beneficial characteristics, when it comes to innovation. Some of these are flexibility, agility in reacting and responding to changed market conditions, rapid communication and decisionmaking within the organisation (Adams, 1982; Cannon, 1985; Vossen, 1998), and closeness to customers (Hadjimanolis, 2000). Further, there is a strong market pull effect in small company product innovation due to their closeness to their customers and their needs (van de Vrande et al., 2009). This way to innovate most often results in incremental innovation (Subrahmanya, 2005). Belotti and Tunälv (1999) and van de Vrande et al. (2009) state that cooperating and working closely with customers during product innovation is common. Mosey et al. (2002) highlight a benefit of close contact with key customers during product innovation: the customers can provide valuable, hard-to-obtain qualitative data about new market conditions. Cannon (1985) explicitly states that support from existing customers is a success factor during product 
innovation in small companies; without this support innovation often fails. Adams and Walbank (1983) propose product innovation to be most successful, if existing customers are targeted.

Belotti and Tunälv (1999) put forward that innovation is rarely strategic in small companies. Lindman (2002) supports this and finds that reactive behavior to innovation is more common than proactive. A high external uncertainty makes long-term strategies less useful, and short-term returns more favorable than longterm returns in innovation (Mazzarol and Reboud, 2005; Westhead and Storey, 1996). Leiponen and Byma (2009) report that small companies prefer speed to market to gain return on innovation investments. The preference for short-term returns is also connected to small companies being very sensitive to any disturbance in the cash flow through the company; a constant cash flow is necessary for the company's existence (Jarvis et al., 2000; Welsh and White, 1981). They find it difficult to wait long for returns on investments or sales (Jarvis et al., 2000; Mazzarol and Reboud, 2005), and securing revenue is highly important for the cash flow (Lawson et al., 2006; Welsh and White, 1981). Small companies have difficulties in coping with a negative cash flow for longer times (Welsh and White, 1981). Mazzarol and Reboud (2005) found one way to secure the cash flow in product innovation: tying customers to the development work allows for an easier diffusion of the new product.

\section{Small companies and resource scarcity}

This research deals with the resources of personnel, knowledge and capital; resource scarcity means lack of the same resources. Material resources, such as plants and machinery, are not included in the research. Many researchers have highlighted the resource scarcity in small companies (see Ghobadian and Gallear, 1996; Rothwell and Dodgson, 1994; Zontanos and Anderson, 2004) and this has been proposed as the greatest obstacle hindering innovation (Adams, 1982; Rothwell and Dodgson, 1994). Operational processes, and urgent problems within these processes, have been found to consume most available resources, not leaving much for innovation (Johansen and Christiansen, 2009). Hadjimanolis (2000) and Nooteboom (1994) express that due to the resource scarcity, small companies need to find extra resources for innovation externally. Adams (1982), Hadjimanolis (2000) and van de Vrande et al. (2009) found that small companies frequently engage in external linkages with external actors in product innovation. Freel (2000) found frequent use of vertical networking with suppliers and customers. Horizontal networking has been found to be less frequent in innovation (van de Vrande et al., 2009), and Lindman (2002) and Mazzarol and Reboud (2005) have found that a majority of small companies develop their innovations alone without 


\section{Löfqvist}

support from horizontal actors. Regarding the informality and structures of small companies' product innovation, Bolinao (2009) proposes that small companies seldom have the resources or infrastructure to perform product innovation in a formal and strategic way. Hadjimanolis (2000) expresses that informality is a strength in small companies, because informal communication, coordination and decision-making seem to be efficient in a small organisational setting. Guimarães et al. (1996) found that the lack of resources in small companies demands considerable creativity to use existing resources efficiently in small companies' product innovation.

Financial bootstrapping (normally called only bootstrapping) is a concept first brought up by Bhide (1992) that deals with how small companies manage their resource scarcity. One of the most used definitions of financial bootstrapping is brought up by Winborg and Landström (2001) as the use of methods to meet the need for resources without relying on long-term external finance. Vanacker et al. (2011) conclude that central in most studies on bootstrapping is the identification and description of methods (bootstrapping methods) used for gaining needed resources from within the company or from the external environment. Most research on bootstrapping (for example: Brush et al., 2006; Carter and Van Auken, 2005; Winborg and Landström, 2001) finds a focus on gaining financial resources in the short term to solve more urgent resource demands. Many of the bootstrapping studies (such as Bhide, 1992; Jones and Jayawarna, 2010; Politis et al., 2012) have focused on newly founded small companies and how these get resources to create the new company and make it run, which is also identified by Tömöry (2010) as the phase of an company lifecycle when bootstrapping is most used. Bhide (1992) and Patel et al. (2011) indicate that companies abandon bootstrapping and go into using more long-term external financing when they get more established on the market.

Given that Mazzarol and Reboud (2005), SCB (2016) and Smith (2009) have found that small companies seldom raise external finance for product innovation, one wonders if they instead bootstrap their innovation efforts. But the research on bootstrapping in product innovation in small companies is scarce. The studies found have been done by Brush et al. (2006), Freear et al. (1995), Harrison et al. (2004), Patel et al. (2011), Smith (2009) and Tömöry (2010), but the findings from these studies are modest. Freear et al. (1995) and Harrison et al. (2004) identified some bootstrapping methods used in product innovation in small companies, such as working overtime, customer-funded product innovation and turning consultant projects into commercial products. Smith (2009) identified bootstrapping methods such as borrowing from suppliers, special deals with customers, the usage of free or low-cost labour, special deals for space and the usage of non-equity funds. Brush et al. (2006) found such bootstrapping methods as prepaid expenses and royalties. 


\section{Summary and research question}

From the above description on small company product innovation and resource scarcity some ways of managing resource scarcity in small company product innovation can be derived:

- Networking to gain resources that the company does not have in house (Adams, 1982; Hadjimanolis, 2000; van de Vrande et al., 2009).

- Qualitative data from key customers about new market conditions within product innovation (Mosey et al., 2002).

- Continual creativity on how to use existing resources in the best way (Guimarães et al., 1996).

- Speed to market to gain return on innovation investments (Leiponen and Byma, 2009).

- Tying customers to the development work to obtain easier diffusion of the new product (Mazzarol and Reboud, 2005).

There are also some identified bootstrapping methods used within product innovation in small companies:

- Working overtime, customer-funded product innovation and turning consultant projects into commercial products (Freear et al., 1995; Harrison et al., 2004).

- Borrowing from suppliers, special deals with customers, the usage of free or low-cost labour, special deals for space and the usage of non-equity funds (Smith, 2009).

- Prepaid expenses and royalties (Brush et al., 2006).

Some approaches and bootstrapping methods seem to be used in product innovation, but how they are combined for managing scarce resources in product innovation is less described in the literature. Much seems to be unknown, especially on how the resource allocation is carried out and transformed into practical innovation work. This justifies the exploratory research question: How do small companies manage resource scarcity in product innovation?

\section{Research Methods}

\section{A longitudinal exploratory case study approach}

Eisenhardt (1989) describes a case study approach as qualitative research that is good at answering exploratory and explanatory research questions such as "why" and "how". Case study methodology is appropriate when the units of study are complex and hard to isolate from the real-life context (Yin, 2003). Pettigrew 


\section{Löfqvist}

(1990) explicitly states that case study research is suitable for studying processes of change, which product innovation are. With the chosen exploratory research question, as well as the characteristics of product innovation as a complex, context-dependent, longitudinal process of change, a longitudinal case study methodology with a few case companies seems to suit this study well and was chosen as research methodology.

\section{Case selection}

Pettigrew (1990) and Yin (2003) stress the importance of choosing cases that will result in an optimal contribution to theory and have a high probability of helping to answer the research questions. Important in this research was to find suitable small established companies that did product innovation. The criteria used in the search for suitable case companies were that the companies should have fewer than 50 employees, be established on the market with operational processes running, have their own products and do product innovation. Furthermore, the researcher had to have good access to the companies so product innovation could be studied in depth and preferably over time. Three companies in Sweden that fulfilled these demands were chosen to be included in the research. Additional aspects that affected the choice of case companies were that the chosen companies differed in the number of new or improved products launched and covered both B2B and B2C products. Choosing two manufacturing and one software company enabled comparing and drawing conclusions about differences that may or may not depend on the specific kind of new product to be developed. Table 1 briefly describes the three studied companies.

\section{Research process}

According to Yin (2003), there are six different main sources of data collection in case studies: documentation, archival records, interviews, direct observation, participant observation and physical artefacts. In this study, all these sources were used in different situations. The participating companies were studied in different ways. Table 2 summarises and describes the different sources of data and data collection methods used in the three studied companies.

The long observation time with companies 1 and 2 made it possible to study product innovation as it occurred in its natural environment, and tacit knowledge (knowledge people are not aware they possess) could be captured. This knowledge could not be articulated in interviews but could be observed in real working situations. Examples of tacit knowledge captured are synergy effects in the usage of resources when product innovation and other processes are intertwined. 
Table 1. Some characteristics of the three companies in the study.

\begin{tabular}{|c|c|c|c|}
\hline & Company 1 & Company 2 & Company 3 \\
\hline Type & Manufacturer B2B & Software/Service B2B & $\begin{array}{l}\text { Manufacturer B2B and } \\
\text { B2C }\end{array}$ \\
\hline Products & $\begin{array}{l}\text { Elevated, earthquake- } \\
\text { proof industrial } \\
\text { floors }\end{array}$ & $\begin{array}{l}\text { Booking systems for } \\
\text { the tourism industry }\end{array}$ & $\begin{array}{l}\text { Small portable } \\
\text { sawmills }\end{array}$ \\
\hline $\begin{array}{c}\text { Foundation of } \\
\text { company }\end{array}$ & 1969 & 1992 & 1989 \\
\hline Employees & 23 & 9 & 25 \\
\hline $\begin{array}{l}\text { Persons involved in } \\
\text { product innovation }\end{array}$ & 5 & 6 & 3 \\
\hline Customers & One big, many small & Many small & Many small \\
\hline Markets & Sweden and the world & Sweden & Sweden and the world \\
\hline $\begin{array}{l}\text { Closeness and } \\
\text { interaction } \\
\text { with current } \\
\text { customers }\end{array}$ & $\begin{array}{l}\text { Quite close, regular } \\
\text { interaction and } \\
\text { communication }\end{array}$ & $\begin{array}{l}\text { Very close, daily } \\
\text { interaction and } \\
\text { communication }\end{array}$ & $\begin{array}{l}\text { Very close, daily } \\
\text { interaction and } \\
\text { communication }\end{array}$ \\
\hline
\end{tabular}

Unlike the data collection in companies 1 and 2, company 3 was studied later and without longitudinal observation, because the company was located far from the researcher's location. Company 3 launched more new or improved products than did companies 1 and 2, and was considered to be particularly efficient and effective in their product innovation. Company 3 was also a very transparent company, with extensive public information about its activities and product innovation projects. The absence of longitudinal observation may be seen as a shortcoming when comparing data across the case companies, but this was compensated for in several ways. Company 3 had much more useful public documentation, than companies 1 and 2, which facilitated obtaining rich information about the company, how they performed their product innovation, and about their products, customers and users. Before meeting and interviewing company 3, the documentation was studied and interview questions were adapted to this material to check the documentation's accuracy. Further, the experiences and knowledge gained from the relatively long data collection period at companies 1 and 2 helped in fine-tuning the questions asked to focus on interesting and relevant areas of product innovation and resource scarcity in small companies. During the $2.5 \mathrm{~h}$ interview with the innovation manager at company 3, answers given appeared to be honest and not in severe conflict with the extensive public information about the company and its product innovation. After the interview time was provided to study company 3's products at 


\section{Löfqvist}

Table 2. The different sources of data used in the studied companies.

\begin{tabular}{|c|c|c|c|}
\hline Source of data & Company 1 & Company 2 & Company 3 \\
\hline Documentation & $\begin{array}{l}\text { Website, brochures, } \\
\text { drawings and } \\
\text { manuals }\end{array}$ & $\begin{array}{l}\text { Website, brochures, flow } \\
\text { charts of the } \\
\text { functionality of } \\
\text { products and manuals }\end{array}$ & $\begin{array}{l}\text { Website, articles, } \\
\text { manuals, brochures, } \\
\text { the company's own } \\
\text { newspaper and } \\
\text { master's theses about } \\
\text { the company }\end{array}$ \\
\hline Archival records & $\begin{array}{l}\text { Drawings and some } \\
\text { documents }\end{array}$ & $\begin{array}{l}\text { Documented information } \\
\text { from customer } \\
\text { meetings }\end{array}$ & Not used \\
\hline Observation & $\begin{array}{l}\text { Both direct and } \\
\text { participant } \\
\text { observation, two days } \\
\text { a week over five } \\
\text { months, } \\
\text { approximately } 6 \mathrm{~h} \text { per } \\
\text { day. Observation of } \\
\text { product innovation as } \\
\text { well as other } \\
\text { activities at the } \\
\text { company. }\end{array}$ & $\begin{array}{l}\text { Both direct and } \\
\text { participant } \\
\text { observation, two days } \\
\text { a week over five } \\
\text { months, } \\
\text { approximately } 6 \mathrm{~h} \\
\text { per day. Observation } \\
\text { of product innovation } \\
\text { as well as other } \\
\text { activities at the } \\
\text { company. }\end{array}$ & $\begin{array}{l}\text { Visited the company, got } \\
\text { a guided walk around } \\
\text { the company's } \\
\text { premises and met } \\
\text { employees in their } \\
\text { work as well as } \\
\text { customers }\end{array}$ \\
\hline Formal interviews & $\begin{array}{l}\text { Formal interviews with } \\
\text { people involved in } \\
\text { product innovation, } \\
1-2 \mathrm{~h} \text { per person, five } \\
\text { interviews }\end{array}$ & $\begin{array}{l}\text { Formal interviews with } \\
\text { people involved in } \\
\text { product innovation, } \\
1-2 \mathrm{~h} \text { per person, six } \\
\text { interviews }\end{array}$ & $\begin{array}{l}2.5 \mathrm{~h} \text { formal interview } \\
\text { with the innovation } \\
\text { manager }\end{array}$ \\
\hline Informal interviews & $\begin{array}{l}\text { Informal interviews and } \\
\text { plentiful informal } \\
\text { discussions and } \\
\text { communication with } \\
\text { almost all persons at } \\
\text { the company }\end{array}$ & $\begin{array}{l}\text { Informal interviews and } \\
\text { plentiful informal } \\
\text { discussions and } \\
\text { communication with } \\
\text { all persons at the } \\
\text { company }\end{array}$ & $\begin{array}{l}\text { A } 15 \text { min informal } \\
\text { interview with the } \\
\text { founder-manager }\end{array}$ \\
\hline Physical artefacts & $\begin{array}{l}\text { Studied the company's } \\
\text { products regarding } \\
\text { design, complexity of } \\
\text { solutions and } \\
\text { technology used }\end{array}$ & $\begin{array}{l}\text { Studied the company's } \\
\text { products regarding } \\
\text { interface, complexity } \\
\text { of solutions and } \\
\text { technology used }\end{array}$ & $\begin{array}{l}\text { Studied the company's } \\
\text { products regarding } \\
\text { design, complexity of } \\
\text { solutions and } \\
\text { technology used }\end{array}$ \\
\hline
\end{tabular}


their location, meet the founder-manager, other employees (working with marketing, sales and engineering design) and the company's customers, and take a guided walk around the company's premises.

During the whole data collection period, collected data was summarised within a $24 \mathrm{~h}$ period to not forget anything and to be able to track the research process. All data were documented in field diaries covering over 600 pages. After the data collection period at the companies all collected data were compiled and summarised and seminars were held at companies 1 and 2, when the findings were presented to the companies for validation. In company 3 , the validation of data was done by e-mail and telephone. Informal follow-up discussions about the findings and interpretation of the data were carried out with the studied companies after the data collection period.

Key to the analysis of the data was to deal with the complexity of the data as well as data with different characteristics, due to the different data collection methods. Data from the different sources had to be sorted out and structured for synthesis. Coding and classifying the data revealed underlying patterns and casual relationships present below the more obvious patterns of data and events. The categories were put into extensive tables. These categories were, when needed, merged together or divided into subcategories. Examples of the categories include where ideas for product innovation originate from, how product innovation was initiated, how product innovation was organised, how new products were designed and how the product reached the customers and users. The data about the product innovation projects in the different companies were later mapped in sequence. By going through the different product innovation projects in each company and then identifying the approaches that affected the usage of resources in the form of personnel, knowledge and capital, different approaches used for managing scarce resources were identified. From the mapped product innovation processes, three different functional categories (see "Analysis and Discussion") of approaches could be derived by inductive reasoning. At last, all found approaches were listed in tables (see Tables 3-5) representing the three functional categories, and a cross-case analysis of the three companies' approaches was performed for drawing conclusions about similarities and differences. At last, all findings were related and compared with existing research on product innovation, small companies and resources.

\section{Findings}

\section{Description of the product innovation in Company 1}

The development of new products is moderate in company 1 . While the company has many good ideas suitable for new products, the ideas are usually not explored, 


\section{Löfqvist}

mainly due to lack of resources. Most resources go into operational processes, such as production and sales, that are needed to run to uphold the cash flow. The company has a history of abandoning product innovation due to lack of resources and lack of customers to support the development work and buy the new product in the end. Occasionally, the company does develop and launch new products when their main customer explicitly asks for a specific new or improved product that will solve some kind of problems that this main customer has. Examples of new products are new versions of current elevated, earthquake-proof industrial floors. These new versions range from geometry changes and added functionality to totally new designs. New products can also be cable-handling systems for electronic equipment that will be installed on the floors. The same main customer also buys the new product when the development work is finished. After this the new products are sold to other customers as well.

All new products are consistent with the company's current product base related to elevated industrial floors. The company does not involve new technology in product innovation but uses already known technology in new ways in new products. Effort is put into reusing solutions in current products in new products to save development work, as well as trying to hold down the complexity of new designs.

The people involved in product innovation have multiple responsibilities in the company and daily working tasks to do in operational processes. This means they must combine daily working tasks with the innovation work. For example, the main person responsible for product innovation also works with quality and environment issues. During product innovation, there is continual creativity on how to use existing scarce resources more efficiently. Different people are often assigned to different tasks, to use existing resources in the most efficient way in different situations. To get more time to do product innovation, working overtime is common.

Product innovation is executed in a cyclical and experimental way, with regular feedback mainly from the main customer but also others in the company's trusted network, such as friends and other small company managers. This feedback adds needed knowledge and keeps the work on track in the right direction. The process is informal and flexible to cope with other operational tasks that need to be handled on a daily basis and to be able to take advantage of resources that can be available with short notice. An example of suddenly available resources is when meetings are cancelled freeing time for innovation work, or when the company suddenly gets in touch with an external actor with specific needed knowledge. The mix of innovation and operational work requires that the ones responsible for product innovation sometimes work on operational and innovation tasks concurrently, such as solving support issues over the phone while doing development work at 
the same time. Product innovation is executed without a formal planning and documentation procedure; no deep analysis of the design problem is done before starting to find solutions. The company once did try to plan and execute product innovation in a formal and systematic way, but this approach did not work mainly because of the flexibility needed in the turbulent internal and external environment of the company. Many unforeseen, urgent problems happened during production or in the customer's use of products, which needed urgent attention and quickly spoiled the planning.

It is not common but lead-user inventions ${ }^{1}$ as described by Hippel (1988) do exist, where the company's customers modify the company's products on their own. Still, lead-user inventions are rare, probably because customers seldom come in contact with the products after they have been put into use. This gives fewer opportunities to do modifications.

\section{Description of the product innovation in Company 2}

Company 2 develops both their main software product, a modularised booking system for the tourism industry, and related customer-specific software products. All new products focus on solving existing customers' problems related to their booking activities, such as new ski school booking modules, tour booking modules and value card loading systems. There is an abundance of good ideas for new products in the company but scarce resources hinder them from examining them all. The company only develops a new product if there is an existing customer or customers that requests and/or supports the development work. The same customer(s) also buys the new product when finished. After this, the new product is offered and sold to other customers as well. Sometimes particular customers finance the development work of new products. Even when a particular customer has financed the development work, the new product is usually offered to other customers as well.

The company executes several different product innovation projects concurrently, and a form of portfolio management is practiced. The main idea with this form of portfolio management is not to spread risk among different innovation projects, but to search for synergy effects between different product innovation projects to save resources and to package customer-specific projects with solutions reusable in other product innovation projects. The novelty value of new products is relatively low, which means that the development work and the final

\footnotetext{
${ }^{1}$ Lead users are users that face needs that will be general in a marketplace earlier than other users, and they benefit greatly if a solution to these needs is obtained. Lead users modify existing products and create lead user-inventions to satisfy their unmet needs (Hippel, 1988).
} 


\section{Löfqvist}

characteristics of the new products can be accurately predicted. Low novelty is a characteristic of design problems in software design, because the constraints of language and systems make the problems more structured and better defined (Jonassen, 2000). This low novelty is the main enabler for this kind of portfolio management and means that larger product innovation projects can be formally planned in advance. Smaller product innovation projects are not planned in a formal way. Except for the formal planning of larger innovation projects, most other aspects of innovation are informal in the company, and the formally planned innovation projects are in practice executed in an informal and flexible way. This enables adjusting them to the turbulent environment of urgent issues in operational processes and to be able to catch suddenly available resources. Intense customer interaction, support issues and technical problems with current products contribute to the turbulence. Suddenly available resources can include the free time that cancelled customer meetings provide. The turbulence also means a great amount of creativity is invested in using resources efficiently, with rearrangement of working tasks and responsibilities. During product innovation, intense discussions are held with the customers to get feedback on the development work. This communication is held through channels such as physical meetings, e-mail and telephone. The company has very close and friendly relations with its customers and interacts with them on daily basis. Frequently, customers themselves are deeply involved in product innovation and do work for free for the company, cocreating the new product. Examples of free work done by customers are requirements setting, prototype testing and marketing of new products to other customers.

Those involved in product innovation have additional responsibilities to handle daily, yielding the intertwinement of innovation and operational work. For example, people sometimes do support tasks and programming at the same time. Another example is when sales, collection of requirements, marketing, support and feedback on product innovation are done during the same contact with customers.

The company does not involve new technology in their product innovation but only use already known technology in new ways, which means that the company does not use the latest Web and computer technology available. A lot of effort is put into reusing already existing booking solutions to save development work as well as to hold down the complexity of new products. There exist lead users who do lead-user inventions for free for the company, but they are not common. One example of lead-user inventions was the programming of a specific booking module by one customer skilled in programming. The rareness of lead users are probably due to the programming knowledge needed to modify the company's products, which the customers seldom have. The employees sometimes work overtime to get more time for product innovation. 


\section{Description of the product innovation in Company 3}

Company 3 has a strong tradition of innovation and several product innovation projects are executed concurrently. There is an abundance of promising ideas for new products in the company which originate from close contact with existing customers. However, all good innovation ideas cannot be explored due to resource constraints. Examples of new products developed are new versions of portable sawmills and related wood transportation and log handling products. Product innovation is carried out by two to three persons who also have other responsibilities in the company and must do operational tasks on a daily basis, which can involve supplier, sales and marketing issues. Therefore, those responsible for product innovation sometimes work on operational and innovation tasks concurrently to use their time more efficiently. Both the internal and external environments are turbulent, with many unforeseen occurrences, such as customer problems with the company's products. The company conducts an intense interaction and communication with its existing customers during product innovation. This is facilitated by the company's very close and friendly relations to its existing customers. Customers visit the company daily. Many lead users exist who design new products or modifications of the company's products that they give away for free to the company. Occasionally these lead-user inventions are further refined by the company and become new products. Examples of realized lead-user inventions are modifications of the company's small portable sawmills to add functionality or eliminate unnecessary steps.

The company finds it hard to evaluate ideas for new products without testing them through some development work. During the development work, the different ideas are compared; the most promising ones survive and become new products in the end. This facilitate developing the best innovation ideas and minimizing the waste of resources on less promising ideas. Those ideas that become new products solve problems that current customers have and also support the development work of the new product. Product innovation is informal, flexible and done in a cyclical, experimental way, exploring the problem and solution spaces concurrently. The flexibility helps the process to cope with the external turbulence as well as take advantage of suddenly available resources that can be used in product innovation. Examples of these resources are unforeseen meetings with customers that can provide valuable knowledge and cancelled meetings that free up time. The product innovation projects are executed without a formal planning and documentation procedure; no deep analysis of the design problem is done before starting to find solutions. Product innovation is open for feedback from customers and others inside the company or in the company's external network. Company 3 actively invites feedback, especially from customers that 


\section{Löfqvist}

want the new product, on their development work to be sure that they are on the right track with the ideas, generated solutions and new products. The involved customers also relatively quickly buy the new product when it is finished. The new product is then sold to other customers as well.

Efforts are made to reuse already existing solutions in new products and reduce the complexity of new designs, which is said to save development work and cause fewer errors. Only already known technology is used in new products, all of which are consistent with the company's current product base of portable sawmills and related wood-refinement products. There is a continual creativity on how to use existing scarce resources more efficiently in product innovation, with rearrangement of working tasks to use existing resources more efficiently. The company intertwines product innovation with operational processes to gain synergy effects on the usage of resources. For example, sales, collection of requirements, marketing, support and feedback on product innovation usually are done during the same contact with customers. The company also outsources much of its production and assembly not only to save money but also to allow time for innovation. They have experience that problems in production and assembly steal too many resources from product innovation. Sometimes the employees work overtime to get more time for innovation work.

\section{Analysis and Discussion}

All three studied companies had an abundance of promising ideas for new products but a scarcity of resources for product innovation, with many resources invested in the daily operational processes in the companies. The challenge for the companies was for their multitasking employees to run their operational processes and do product innovation at the same time. To deprioritise the operational processes to get more resources to product innovation was not an option for any of the companies, because such operational processes as production and sales must run to maintain the much needed steady cash flow. Small companies are sensitive to any disturbance in cash flow (Jarvis et al., 2000; Mazzarol and Reboud, 2005; Welsh and White, 1981). The findings show that the studied companies used many different approaches during their product innovation to manage their resource scarcity. These approaches were mainly possible because of the companies' small organisational structure, which resulted in natural flexibility, with fast decision making and coordination allowing multifunctional roles among employees, as well as the close contact and communication with the companies' customers. The companies used several approaches for increasing resources as well as several approaches for using existing resources more 
efficiently. Then they used some approaches to secure a fast payback on resources invested in product innovation. These three separate functions that the different approaches fulfil create three different functional categories of approaches that will be further described and discussed below in "Approaches for increasing resources", "Approaches for using existing resources more efficiently" and "Approaches for securing fast payback on resource put into product innovation". In "Concluding discussion," the approaches as well as their implications for product innovation will be further discussed.

\section{Approaches for increasing resources}

Table 3 shows approaches identified for increasing the amount of resources in the studied companies. The studied companies had close contact with their customers, which is common for small companies (Hadjimanolis, 2000). For example, companies 2 and 3 had very close and friendly relations with their customers and interacted daily through different communication channels. This closeness resulted in networks of trusted customers in which communication was easy. They gave the companies accurate market information and knowledge of new product requirements and usage. But networking, closeness and communication with customers involved not only gaining valuable knowledge needed in product innovation but also increasing resources in other ways. The studied companies did not start a product innovation project unless a clearly defined current customer or customers needed or demanded the potential new products. This approach has several resource-increasing benefits. The customers want the product to be developed because it will solve their problems, so they are willing to support the development work and contribute their own resources to get the product realised. This, together

Table 3. Approaches for increasing resources.

\begin{tabular}{|c|c|c|c|}
\hline Approaches & Company 1 & Company 2 & Company 3 \\
\hline $\begin{array}{l}\text { Only invest in and realise product innovation if existing } \\
\text { customer(s) are involved and want the new product }\end{array}$ & $\bullet$ & $\bullet$ & • \\
\hline $\begin{array}{l}\text { Interaction, communication and feedback from } \\
\text { horizontal actors in the company's network }\end{array}$ & $\bullet$ & & • \\
\hline $\begin{array}{l}\text { Customers do practical innovation work for free for the } \\
\text { company }\end{array}$ & & $\bullet$ & $\bullet$ \\
\hline Direct financing of development work from customers & & • & \\
\hline $\begin{array}{l}\text { Outsource resource-draining activities such as } \\
\text { production and assembly }\end{array}$ & & & $\bullet$ \\
\hline Working overtime & • & • & • \\
\hline
\end{tabular}




\section{Löfqvist}

with the friendly and close contact and communication, means that these customers are available through the whole product innovation project to ask for advice, give ideas and feedback, and validate that product innovation is proceeding in the right direction. The supportive customers were involved in product innovation, which for companies 2 and 3 means customers did innovation work for free for the companies. In Company 2, the customer did work such as requirement setting, prototype testing and marketing, and in Company 3, the customers created many lead-user inventions that they gave away for free, saving on development work for the company if they adopted the invention and refined it as one of their own products. This adoption of lead-user inventions has a great resource-increasing effect. It benefits the companies when customers identify real and relevant problems but also do their own development work and create product concepts for free. A lower complexity and simpler technology in current and new products facilitated that customer could more easily modify the products and create leaduser inventions. Access to modify the products seems also to be important for the creation of lead-user inventions. Company 1's products had low complexity and used simpler technology, but users did not have access to modify the products after sale, which resulted in a low amount of lead-user inventions.

Adams (1982), Hadjimanolis (2000) and van de Vrande et al. (2009) found that small companies use external linkages with external actors to get resources for product innovation. All three companies mainly used their existing customers to get these resources. Companies 1 and 3 also networked with horizontal actors to gain additional feedback, knowledge and ideas. This kind of horizontal networking was not practiced in Company 2, which only communicated and networked with current customers during their product innovation. No supplier integration could be observed as part of product innovation in the studied companies. Freel (2000) states that vertical networking is the most important kind of networking in product innovation in small companies. Since the findings show modest horizontal networking and no supplier integration, this may indicate that existing customers are the most important resource-providing external actors within product innovation in small companies.

Company 3 outsourced much of its production and assembly to suppliers not only because it was cheaper but also because they had experienced problems when these activities steal too many resources from product innovation. In Company 2 , specific customers sometimes pay for the development work, creating a resource buffer and securing cash flow. All companies worked overtime when needed to be able to do both product innovation and operational tasks. 


\section{Approaches for using existing resources more efficiently}

Approaches for using existing resources more efficiently deals with how the studied companies increased their efficiency of their own resources in their product innovation and operational processes during product innovation. Efficiency in this context means using their own resources smarter, minimising the need for resources, and creating more from the same amount of resources. Table 4 shows the different approaches found on how to use existing resources more efficiently.

The studied companies' use of existing customers in product innovation was found to save resources in several ways. The customers' appreciation and support of an innovation idea quickly shows the company if an innovation idea has commercial value. This decreases the need for resource-demanding marketing research. Customer feedback on product innovation that helped to steer the development work in the right direction was further found to decrease the probability that too many resources are put into less suitable solutions. This continuous feedback also decreases the risk that the new product will overshoot the requirements, which saves on resources. These customers also facilitate a fast and resource-efficient commercialisation, with low transaction costs, when the development work is finished. These already involved customers are ready to buy the new product quickly. The close interaction and communication with some

Table 4. Approaches for using existing resources more efficiently.

\begin{tabular}{|c|c|c|c|}
\hline Approaches & Company 1 & Company 2 & Company 3 \\
\hline $\begin{array}{l}\text { Only invest in and realise product innovation if } \\
\text { existing customer(s) are involved and want the new } \\
\text { product }\end{array}$ & $\bullet$ & $\bullet$ & $\bullet$ \\
\hline $\begin{array}{l}\text { New products consistent with the company's current } \\
\text { product base }\end{array}$ & $\bullet$ & $\bullet$ & $\bullet$ \\
\hline Informal and flexible product innovation & $\bullet$ & $\bullet$ & $\bullet$ \\
\hline $\begin{array}{l}\text { Formal planning of the use of resources in a portfolio } \\
\text { management process }\end{array}$ & & $\bullet$ & \\
\hline $\begin{array}{l}\text { Intertwinement between product innovation and } \\
\text { operational processes }\end{array}$ & & $\bullet$ & $\bullet$ \\
\hline $\begin{array}{l}\text { Intertwinement between different product innovation } \\
\text { projects }\end{array}$ & & $\bullet$ & \\
\hline Reusing existing solutions in product innovation & $\bullet$ & $\bullet$ & $\bullet$ \\
\hline $\begin{array}{l}\text { Continual creativity on how to use existing scarce } \\
\text { resources more efficiently }\end{array}$ & $\bullet$ & $\bullet$ & $\bullet$ \\
\hline $\begin{array}{l}\text { Usage of known technology and low complexity of } \\
\text { new products }\end{array}$ & $\bullet$ & • & $\bullet$ \\
\hline Competing innovation ideas & & & - \\
\hline
\end{tabular}




\section{Löfqvist}

targeted existing customers was an efficient approach to get trustworthy, qualitative market information needed in product innovation, resembling the findings by Mosey et al. (2002). This knowledge collection was further found to be easily combined with operational processes in companies 2 and 3 . The close and friendly relations with existing customers also facilitated an easy identification and adoption of lead-user inventions for Company 3.

New products were all consistent with the particular company's current products. No new products were developed that deviated from their current product range, perhaps because overcoming the technology and market uncertainty and risk is too resource demanding.

The studied companies executed their product innovation in an informal and flexible way, which matches findings by Bolinao (2009). Company 2 distinguished itself from the two other companies by formal planning of larger product innovation projects. This planning was facilitated by the fact that the company creates software, which has low-novelty design problems (Jonassen, 2000). This low novelty means that the final product could be determined with great certainty in advance. Because most characteristics and properties were known in advance, the development work was easier to foresee and plan. Still, the product innovation in Company 2 was executed in a flexible and informal way.

A great amount of flexibility was needed in the studied companies since both interaction with the involved customers and operational processes was handled by the ones involved in product innovation. Furthermore, the studied small companies work in turbulent environments, with many unforeseen things happening daily. The turbulence resulted from the many urgent things that arose had to be dealt with, such as trouble in production or sales, or customer's problems with the company's current products. Unresolved production and sales problems would quickly affect the cash flow negatively, an undesirable risk because small companies are very sensitive to disturbance and dips in the cash flow (Jarvis et al., 2000; Mazzarol and Reboud, 2005; Welsh and White, 1981). The customers' problems with current products must also be solved quickly, because good relations with current customers increase the probability that they return for purchases, which also benefits cash flow. Flexibility seems to be beneficial to product innovation because it helps the company to cope with the external turbulence, operational processes and cash-flow issues, while also helping in utilising available resources.

The informality in product innovation was striking in the studied companies. The natural setting for product innovation in small companies is a small organisation. Formality and documentation seem not to be needed, because most important things in product innovation seem to be relatively easily communicated and understood in a small organisation, which matches findings by Hadjimanolis 
(2000). The informality also suited the interaction with the existing customers involved in product innovation and was a better match with the companies' other informal operational processes. Formal approaches for product innovation demand too many resources, according to Bolinao (2009). Formalising product innovation seems not to yield many advantages in small companies, but only creates unnecessary work. We can conclude that informality and flexibility saves on resources in small companies' product innovation.

The studied companies intertwined their processes to be able to use the same resources for different purposes, increasing efficiency. In all three companies, persons sometimes concurrently worked on both product innovation and operational tasks to use existing resources more efficiently. However, companies 2 and 3 intertwined product innovation and operational work more than Company 1 did, to get synergy effects in the usage of resources. An example of this intertwinement was when sales, collection of requirements, marketing, support and feedback on product innovation occurred during the same contacts with customers. Company 2 , which was accustomed to running several product innovation projects concurrently, actively searched for synergy effects and intertwinement between these innovation projects so several projects could use the same resources. Work done in one product innovation project that also could be used in another saves on resources. This was done with the help of their form of portfolio management, planning the product innovation projects for synergy effects in the use of resources. Reusing existing solutions was another form of intertwinement of different product innovation projects practiced by all three studied small companies, because it also saved development resources. Company 2 was the only one that more strategically created solutions in one product innovation project so they could be reused in future product innovation projects. Especially in customerfinanced product innovation effort was invested in work that could be reused in other, not customer-financed product innovation. In general, there was a continual creativity on how to use existing scarce resources in the most efficient way in the examined companies' product innovation.

Regarding technology, all companies only used already known technology in their new products. It would probably be too resource demanding to develop new technology themselves. Known technology used in new novel ways probably demands fewer resources to handle than developing, buying or learning new technology. The complexity of new products was minimised, which meant fewer sources of error in the development work and saves on resources.

Company 3 also let different innovation ideas compete for resources. Company 3 had many promising innovation ideas but not the resources to realise them all. Starting development of several ideas allowed them to be evaluated properly in comparison with other innovation ideas. Thus, not too many resources were put 


\section{Löfqvist}

on the less-good innovation ideas, and the best ideas got resources for further development.

\section{Approaches for securing fast payback on resources put into product innovation}

The two previous categories of approaches dealt with how resources were gained to do product innovation in the studied companies. However, product innovation is not only about getting and spending resources on creating new products. It is also about getting resources back through commercialisation of the new products. The development of the new product consumes a lot of resources (Smith, 2009); to get a fast return seems to be especially crucial for small companies. Uncompensated development work can create dips in the cash flow that can seriously harm small companies, since they are so vulnerable to disturbances in the cash flow and cannot stand negative cash flow for long (Welsh and White, 1981). This justifies a third category of approaches, used for securing a fast payback on resources put into product innovation, as outlined in Table 5.

The studied companies only did market pull innovation; the market consisted of the companies' existing customers, not product innovation aimed at new markets or new customers. A need from the market gives some guarantee that the new products can be sold and yield a payback. No technology push innovation was done; the companies do not seem to have the resources to develop new technology by themselves and do more technologically radical product innovation. Furthermore, the companies focus on solving existing customers' problems with new products, which easily shows the value to the customers and makes them want the new product to solve their problem. This provides further guarantee that the new product can be sold and yield a payback. When existing customers want the potential new product, it shows that the innovation idea has commercial value, which lowers the market uncertainty and risk. This further facilitates a fast and

Table 5. Approaches for securing a fast payback on resources put into product innovation.

\begin{tabular}{|c|c|c|c|}
\hline Approaches & Company 1 & Company 2 & Company 3 \\
\hline Market pull only & - & - & - \\
\hline $\begin{array}{l}\text { Focus on solving existing customers' problems with } \\
\text { new products }\end{array}$ & - & - & - \\
\hline $\begin{array}{l}\text { Only invest in and realise product innovation if } \\
\text { existing customer(s) are involved and want the new } \\
\text { product }\end{array}$ & $\bullet$ & $\bullet$ & $\bullet$ \\
\hline
\end{tabular}


easy commercialisation when the development work is finished. The involved customers buy the new product, which gives a fast return on resources put into product innovation and helps stabilise the cash flow. Later on, the new products can be sold to other customers, which further increases the return on resources put into product innovation and contributes to the cash flow.

\section{Concluding Discussion}

Financial bootstrapping is defined as the use of methods to meet the need for resources, without relying on long-term external finance (Winborg and Landström, 2001). No long-term external finance, such as from traditional financial institutions or venture capital, was used to get resources to product innovation; the companies mainly used their own and existing customers' resources. This means that the studied small companies bootstrapped their product innovation and that the found approaches are bootstrapping methods. This shows that bootstrapping is practiced not only for company development in newly started small companies, as previous research has mainly highlighted (Bhide, 1992; Jones and Jayawarna, 2010; Politis et al., 2012), but also extensively during product innovation in small established companies. This result was only modestly indicated previously. Bhide (1992), Patel et al. (2011) and Tömöry (2010) indicate that bootstrapping is abandoned when companies become established on the market, but our findings show that it continues during product innovation. The task of creating a new small company and doing product innovation in a small established company can both be argued to be highly resource-demanding tasks in a highly resource-constrained environment. In both cases, something new and complex is to be created, uncertainty is involved and the creation must be accepted and survive on the market. In the creation of a new company, resources are needed to build up operational processes such as production and sales to get cash flow. But when these operational processes consume most of the available resources, resources for product innovation are lacking and bootstrapping is needed.

Several bootstrapping methods used by the studied companies were found in prior research: networking for resources (Adams, 1982; Hadjimanolis, 2000; van de Vrande et al., 2009), the usage of current customers for qualitative market information (Mosey et al., 2002), high creativity in the use of resources (Guimarães et al., 1996) and tying customers to the development work to facilitate the diffusion of the new product (Mazzarol and Reboud, 2005). The bootstrapping methods of working overtime and customer-funded innovation (Freear et al., 1995; Harrison et al., 2004), as well as the usage of free or low-cost labour (Smith, 2009) when customers do innovation work for free, are also confirmed. In addition 


\section{Löfqvist}

to these confirmations, this study identifies several new bootstrapping methods. Examples include the approach to only invest in and realise product innovation if existing customer(s) are involved and want the new product, the intertwinement of the product innovation projects, the resource efficiency in the usage of informal and flexible product innovation, the reusage of existing solutions, and the use of lead users and their inventions. However, even more interesting may be the three overall functions the different bootstrapping methods fulfil. These overall functions create three categories of bootstrapping methods in product innovation in small companies, as follows:

- To increase resources.

- To use existing resources more efficiently.

- To secure fast payback on resources put into product innovation.

Some bootstrapping methods render functions in all three categories, such as "Only invest in and realise product innovation, if existing customer(s) are involved and want the new product". When existing customers seem to be the most important external actors providing resources within product innovation, these bootstrapping methods seem to explain much of the logic of how resource scarcity is managed within small companies' product innovation. One can even argue that resource scarcity shapes the studied companies' product innovation, forcing the companies to involve and use the market, through involvement of existing customers, from the very beginning and during the whole product innovation project. To first develop the new product and then search for customers may not work because of the lack of resources. The studied companies did not realize product innovation, nor did they invest much in development work, if no existing customers were present that supported the innovation idea, even if the innovation ideas were considered very promising. The innovation ideas could be discussed and examined to some degree and some development work could be expended, but they were never fully developed into finished new products. Possible reasons for this were the uncertainty about the innovation idea's commercial value. It may also be the case that the studied companies could not proceed with an innovation idea even if they wanted to, because of the lack of resources. Existing customers are found to provide a considerable amount of resources needed in product innovation, and these resources would be absent if these customers were not present. This is probably most relevant regarding the resource of knowledge. Without involved existing customers who provide extensive knowledge on the potential new products' requirements, usage and market conditions, the companies would probably have difficulties in knowing exactly what to develop to meet customer and market demands and needs. This may be the explanation to Cannon's (1985) statements 
regarding support from existing customers being a success factor in product innovation in small companies and innovation often failing without it. It may also explain Adams and Walbank (1983) assertion that product innovation in small companies is most successful if existing customers are targeted. Supportive existing customers seem to be needed within product innovation, because they provide deep and rich knowledge on how the company shall meet the needs and demands from the market.

No examples of product innovation creating new products unsuccessful on the market were found in the studied companies. Such products never became fully developed and launched. No existing customers could be coupled with these innovation ideas, which means that these innovation ideas lacked needed resources to proceed to be fully developed into new products. It seems that an absence of existing customers in product innovation results in a lack of resources that itself hinders these innovation ideas from being realised into new products. The resource scarcity seems to prevent less suitable innovation ideas from being developed and launched. This, however, need not mean the innovation ideas are bad, not are innovative or do not have potential in a broader perspective. It seems only to mean that the innovation ideas not are suitable for different reasons to the companies' markets of existing customers, which make them unsuitable for use in creating new products. There seems to be a powerful mechanism in product innovation in small companies that makes sure that only "the right" new products are realised. The right new products are those that solve existing customers' problems, are desired by existing customers, can be developed in collaboration with supportive existing customers, can be quickly commercialised and benefit cash flow. This way to innovate seems to have both pros and cons. The pros are (a) new products accepted by the market are realised in a resource-efficient way and (b) unsuccessful innovation seem to be prevented. The cons are that it seems to exclude (a) more technologically radical innovation and (b) innovation targeting new markets.

\section{Conclusions, Further Research and Managerial Implications}

To manage resource scarcity in their product innovation, the studied small companies were found to use many different bootstrapping methods, which can be divided into three different functional categories:

- To increase resources.

- To use existing resources more efficiently.

- To secure fast payback on resources put into product innovation. 


\section{Löfqvist}

Due to their resource scarcity, the studied companies were further found to use an innovation strategy only involving new products done with known technology and targeting existing markets. This way to innovate creates new products in a resource-efficient way that is accepted by the companies' existing markets. It seems to prevent unsuccessful product innovation but at the same time exclude more technologically radical innovation and innovation targeting new markets.

The limited number of cases in this study limits generalisation. To enable generalisations, the findings and conclusions must be tested in a quantitative way, which is an opportunity for further research. Furthermore, it is unknown if the results are valid for companies other than small, relatively independent established companies. It would be interesting to test the findings on newly started companies with immature relations to customers, companies financed with external venture capital, or franchise companies that belong to a larger overall organisation.

Managers can benefit from this study's identification and classification of bootstrapping methods. This categorisation of bootstrapping methods may be a suitable frame of reference when managing resource scarcity in product innovation in small companies. Furthermore, this study emphasises the importance and benefits for small companies to involve existing customers in product innovation - they seem to provide crucial resources enabling product innovation.

\section{References}

Adams, A (1982). Barriers to product innovation in small firms: Policy implications. International Small Business Journal, 1(1), 67-86.

Adams, A and M Walbank (1983). Perceived and acted out training needs in small manufacturing firms. International Small Business Journal, 2(1), 46-51.

Belotti, C and C Tunälv (1999). Acquisition of technological knowledge in small and medium-sized manufacturing companies in Sweden. International Journal of Technology Management, 18(3/4), 353-372.

Bhide, A (1992). Bootstrap finance: The art of start-ups. Harvard Business Review, 70(6), $109-117$.

Bolinao, ES (2009). Innovation process and performance in small- to medium-sized firms: A conceptual framework. DLSU Business \& Economic Review, 19(1), 71-80.

Brush, CG, NM Carter, EJ Gatewood, PG Greene and MM Hart (2006). The use of bootstrapping by women entrepreneurs in positioning for growth. Venture Capital, $8(1), 15-31$.

Cannon, T (1985). Innovation, creativity and small firm organization. International Small Business Journal, 4(1), 34-41.

Carter, RB and H Van Auken (2005). Bootstrap financing and owners' perception of their business constraints and opportunities. Entrepreneurship \& Regional Development, 17(2), 129-144. 
Eisenhardt, KM (1989). Building theories from case study research. The Academy of Management Review, 14(4), 532-550.

European Union (2003). C(2003) 1422, Commission Recommendation of 6 May 2003 Concerning the Definition of Micro, Small and Medium-Sized Enterprises. Available at: http://eur-lex.europa.eu/LexUriServ/LexUriServ.do?uri=OJ:L:2003: 124:0036:0041:en:PDF accessed on 26 November 2010.

Freear, J, JE Sohl and WE Wetzel, Jr (1995). Who bankrolls software entrepreneurs? In Proc. Babson College Entrepreneurship Research Conference, April 9-13, 1995, London Business School, London, UK.

Freel, MS (2000). External linkages and product innovation in small manufacturing firms. Entrepreneurship \& Regional Development, 12(3), 245-266.

Ghobadian, A and DN Gallear (1996). Total quality management in SMEs. Omega, 24(1), 83-106.

Guimarães, L, J Penny and S Moody (1996). Product design and social needs: The case of northeast Brazil. International Journal of Technology Management, 12(7-8), 850-864.

Hadjimanolis, A (2000). A resource-based view of innovativeness in small firms. Technology Analysis \& Strategic Management, 12(2), 263-281.

Harrison, RT, CM Mason and P Girling (2004). Financial bootstrapping and venture development in the software industry. Entrepreneurship \& Regional Development, 16(4), 307-333.

Hippel, E von (1988). The Sources of Innovation. New York: Oxford University Press.

Jarvis, R, J Curran, J Kitching and G Lightfoot (2000). The use of quantitative and qualitative criteria in the measurement of performance in small firms. Journal of Small Business and Enterprise Development, 7(2), 123-134.

Johansen, J and M Christiansen (2009). Experience with innovation checks: A case study with 46 companies in Denmark. Software Process Improvement and Practice, 14(5), 263-270.

Jonassen, DH (2000). Toward a design theory of problem solving. Educational Technology, Research and Development, 48(4), 63-85.

Jones, O and D Jayawarna (2010). Resourcing new businesses: Social networks, bootstrapping and firm performance. Venture Capital: An International Journal of Entrepreneurial Finance, 12(2), 127-152.

Lawson, CP, PJ Longhurst and PC Ivey (2006). The application of a new research and development project selection model in SMEs. Technovation, 26(2), 242-250.

Leiponen, A and J Byma (2009). If you cannot block, you better run: Small firms, cooperative innovation, and appropriation strategies. Research Policy, 38(9), 14781488.

Lindman, MT (2002). Open or closed strategy in developing new products? A case study of industrial NPD in SMEs. European Journal of Innovation Management, 5 (4), 224-236. 


\section{Löfqvist}

Mazzarol, TW and S Reboud (2005). Customers as predictors of rent returns to innovation in small firms: An exploratory study. International Journal of Entrepreneurship and Innovation Management, 5(5/6), 483-494.

Mosey, S, JN Clare and DJ Woodcock (2002). Innovation decision making in British manufacturing SMEs. Integrated Manufacturing Systems, 13(3), 176-183.

Nooteboom, B (1994). Innovation and diffusion in small firms; Theory and evidence. Small Business Economics, 6(5), 327-347.

Patel, PC, JO Fiet and JE Sohl (2011). Mitigating the limited scalability of bootstrapping through strategic alliances to enhance new venture growth. International Small Business Journal, 29(5), 421-447.

Pettigrew, AM (1990). Longitudinal field research on change: Theory and practice. Organization Science, 1(3), 267-292.

Politis, D, J Winborg and A Lindholm Dahlstrand (2012). Exploring the resource logic of student entrepreneurs. International Small Business Journal, 30(6), 659-683.

Rothwell, R and M Dodgson (1994). Innovation and size of firm. In: The Handbook of Industrial Innovation, M Dodgson and R Rothwell (Eds.) pp. 310-324. Vermont: Edward Elgar Publishing.

SCB (2016). Statistic Sweden, Innovation activity in Swedish enterprises 2012-2014. Available at: http://www.scb.se/en_/Finding-statistics/Publishing-calendar/Show-detailed-information/?publobjid=27265, accessed on 7 July 2016.

Smith, D (2009). Financial bootstrapping and social capital: How technology-based startups fund innovation. International Journal of Entrepreneurship and Innovation Management, 10(2), 199-209.

Subrahmanya, B (2005). Technological innovation in Indian small enterprises: Dimension, intensity and implications. International Journal of Technology Management, 30(1/ 2), 188-204.

Tömöry, EM (2010). Nurturing innovation through bootstrap financing: An entrepreneurial perspective. In Proc. Innovation Driven Entrepreneurship International Scientific Conf., BMRA 2010, 14-16 October 2010, ISM University of Management and Economics, Vilnius, Lithuania.

Vanacker, T, S Manigart, M Meuleman and L Sels (2011). A longitudinal study on the relationship between financial bootstrapping and new venture growth. Entrepreneurship \& Regional Development, 23(9-10), 681-705.

van de Vrande, V, J de Jong, W Vanhaverbeke and M de Rochemont (2009). Open innovation in SMEs: Trends, motives and management challenges. Technovation, 29(6/7), 423-437.

Vossen, RW (1998). Relative strengths and weaknesses of small firms in innovation. International Small Business Journal, 16(3), 88-94.

Welsh, JA and JF White (1981). A small business is not a little big business. Harvard Business Review, 59(4), 18-32.

Westhead, P and D Storey (1996). Management training and small firm performance: Why is the link so weak? International Small Business Journal, 14(4), 13-24. 
Winborg, J and H Landström (2001). Financial bootstrapping in small business: Examining small business managers' resource acquisition behaviors. Journal of Business Venturing, 16(3), 235-254.

Yin, RK (2003). Case Study Research: Design and Methods, 3rd edn. London: Sage Publications.

Zontanos, G and AR Anderson (2004). Relationships, marketing and small business: An exploration of links in theory and practice. Qualitative Market Research: An International Journal, 7(3), 228-236. 